\title{
Meaning of leprosy for people who have experienced treatment during the sulfonic and multidrug therapy periods ${ }^{1}$
}

\author{
Karen da Silva Santos ${ }^{2}$ \\ Cinira Magali Fortuna ${ }^{3}$ \\ Fabiana Ribeiro Santana ${ }^{4}$ \\ Marlene Fagundes Carvalho Gonçalves ${ }^{3}$ \\ Franciele Maia Marciano ${ }^{5}$ \\ Silvia Matumoto ${ }^{3}$
}

Objective: to analyze the meanings of leprosy for people treated during the sulfonic and multidrug therapy periods. Method: qualitative nature study based on the Vigotski's historical-cultural approach, which guided the production and analysis of data. It included eight respondents who have had leprosy and were submitted to sulfonic and multidrug therapy treatments. The participants are also members of the Movement for Reintegration of People Affected by Leprosy. Results: the meanings were organized into three meaning cores: spots on the body: something is out of order; leprosy or hanseniasis? and leprosy from the inclusion in the Movement for Reintegration of People Affected by Leprosy. Conclusion: the meanings of leprosy for people submitted to both regimens point to a complex construction thereof, indicating differences and similarities in both treatments. Health professionals may contribute to the change of the meanings, since these are socially constructed and the changes are continuous.

Descriptors: Leprosy; Therapeutics; Prejudice; Public Health; Cultural Characteristics.

\footnotetext{
1 Supported by Conselho Nacional de Desenvolvimento Científico e Tecnológico (CNPq), Brazil, process \# 134732/2012-0.

2 Undergraduate student in Nursing, Escola de Enfermagem de Ribeirão Preto, Universidade de São Paulo, PAHO/WHO Collaborating Centre for Nursing Research Development, Ribeirão Preto, SP, Brazil. Scholarship holder from Conselho Nacional de Desenvolvimento Científico e Tecnológico (CNPq), Brazil.

${ }^{3}$ PhD, Professor, Escola de Enfermagem de Ribeirão Preto, Universidade de São Paulo, PAHO/WHO Collaborating Centre for Nursing Research Development, Ribeirão Preto, SP, Brazil.

${ }^{4}$ Doctoral student, Escola de Enfermagem de Ribeirão Preto, Universidade de São Paulo, PAHO/WHO Collaborating Centre for Nursing Research Development, Ribeirão Preto, SP, Brazil. Adjunct Professor, Universidade Federal de Goiás, Catalão, GO, Brazil.

5 MSc, RN, Unidade de Saúde de Uberlândia, Secretaria Municipal de Saúde de Uberlândia, Uberlândia, MG, Brazil.
}

Corresponding Author: Cinira Magali Fortuna

Universidade de São Paulo. Escola de Enfermagem de Ribeirão Preto Departamento Materno-Infantil e Saúde Pública

Av. Bandeirantes, 3900

Bairro: Monte Alegre

CEP: 14040-902, Ribeirão Preto, SP, Brasil

E-mail: fortuna@eerp.usp.br
Copyright ( 2015 Revista Latino-Americana de Enfermagem This is an Open Access article distributed under the terms of the Creative Commons Attribution Non-Commercial License (CC BY-NC).

This license lets others distribute, remix, tweak, and build upon your work non-commercially, and although their new works must also acknowledge you and be non-commercial, they don't have to license their derivative works on the same terms. 


\section{Introduction}

Leprosy is an infectious, chronic and slowly progressive disease. Hansen's bacillus predominantly affects the skin and peripheral nerves and may cause deformity and disability. Currently, leprosy has treatment and cure. However, the late diagnosis, the large number of patients with sequelae, the lack of awareness of the population and the difficulties of access to comprehensive care, from prevention to rehabilitation, cause social discrimination $^{(1-2)}$.

The construction of the social imaginary that punished individuals with the disease consisted of the profound approximation of the binomials health/illness and life/death. In the Middle Ages, the fight against leprosy was focused on the sick individual, with its extermination or exclusion from the community. Such practices were preceded by civil rituals of processes and/or judgments and religious rituals, in which the sick person was officially declared dead, with the possibility of resurrection after death, according to the God's will(3).

Hansen's disease is present in Brazil since the beginning of colonization, accompanied by social marginalization of patients. The compulsory isolation policy was outlined in the Bergen Conference (1909) and this practice was adopted by most endemic countries, which included isolation of patients, removal of their children, medical examination of all people who lived with the patient and incentive for its study and research(3).

The speech and the practice of compulsory isolation in Brazil can be divided into five main periods. From 1900 to 1920 , the first prophylactic policies emerged. In the second period, from 1921 to 1930, the National Department of Public Health was founded and the discussions on isolation methods were intensified. The third period, from 1931 to 1945 , corresponds to the time of Getúlio Vargas, when the compulsory isolation was implemented, the large asylumcolonies were built and the sulfonic treatment began to be used in Brazil (in 1944). In the fourth period, from 1946-1967, the international congresses discouraged, or even criticized the isolation actions. In 1962, compulsory isolation ended in Brazil, except in São Paulo. Finally, in the fifth period, from 1967 forwards, compulsory isolation was replaced by ambulatory treatment at Health Centers or Hospitals. However, asylum-colonies remained due to the long period of social segregation and the difficulty of inclusion into society ${ }^{(3)}$.

From 1986, it has developed a new treatment with the use of multidrug therapy, which consisted of a set of three drugs, namely: sulfone (dapsone), rifampicin and clofazimine. This treatment was standardized by the World Health Organization (WHO) and represents the current form of treatment ${ }^{(1)}$.

Hence, the sulfonic period in Brazil comprises the years from 1944 to 1986 and the multidrug therapy period is from 1986 to the present.

In this context, there was the need to create a place where people affected by leprosy could strengthen themselves, in order to claim their rights and make clear to society the factors involving this pathology, resignifying and demystifying leprosy(4-5).

On June 6, 1981, the internal former patients of asylum-colonies funded the Movement for Reintegration of People Affected by Leprosy (MORHAN). It currently has cores in 24 states of Brazil, with more than one core by region, and aims to promote educational activities focused on prevention, early diagnosis, treatment, rehabilitation and social participation of people affected by leprosy(4-5).

Thus, the understanding of the meaning of leprosy for people who experienced these changes in treatment is important for the apprehension of the re-signification processes, since these will change the way that society deals with contagious diseases.

The Vigotskian approach for nursing research or other research areas represents one of the possibility not only to describe reality, but also to explain it, by investigating its processes, relationships and transformations. It is also one of the possibilities for developing actions, whether in education, care, management and research due to the importance of the process of interaction mediated by language in the construction of knowledge(6).

In nursing, according to a survey at MEDLINE, LILACS and BDENF databases, its use in Brazil as theoretical reference appeared in the $1990 s^{(6)}$. However, there is, in the literature, no study referring to the meanings of leprosy to patients and/or former patients on the Vigotskian perspective.

Accordingly, to investigate the meaning of words and expressions of the former leprosy patients about their history is to revive, reaffirm and re-edit the past. To recount their experiences will enable the opening of a rich range of thoughts. Thus, the goal of this study is to analyze the meaning of leprosy for people who were treated during the sulfonic and multidrug therapy periods.

\section{Method}

This is a qualitative study with the Vigotskian methodological and theoretical approach as 
reference*(7-8), in which the researcher is placed as an element that is part of the study problem, not as a neutral observer. Thus, its action in the field of study and the effects of this action are also relevant materials for research.

The Vigotskian approach considers the human psychological functioning as social and historical. Thus, the instruments, signs and all elements of the human environment, with cultural meaning, are provided by the relationships among men. Language is the fundamental symbolic system for communication between people and the establishment of meanings, which interprets the objects, events and situations of the real world(7).

The meaning refers to the objective relationships system, formulated in the word's development process, containing a stable understanding core, shared by all the people who use it. The sense refers to the meaning of the word for each individual and composed by the relationships established in the context of use of the word and in emotional experiences of the individual(8).

The connection between meaning and sense occurs in a dialectic of forces that is part of the meaning of the word, which cannot be neglected in the study of human processes. By aggregating the notion of meaning, commitment is expanded, reaching various forms of work on the meaning field(9).

Data collection was carried out from October to December of 2012, at one of MORHAN cores within the State of São Paulo, Brazil, where one of the researchers, a healthcare course student, attended actively the activities for almost a year. This researcher was trained along with other researchers responsible for conducting the interviews and has developed research activities for four years.

The study included eight people who have had leprosy and were members of the movement, with four being treated during the sulfonic period and the other four in the period of multidrug therapy. The selection criteria were: members of MORHAN who had leprosy and were treated in the respective periods. Exclusion criteria were: individuals not presenting good health conditions to provide health information.

Semi-structured interviews were conducted in person and were composed of closed questions, to characterize the individuals, and open questions so that the dialogue between the researcher and the respondent could flow freely. Respondents were approached during activities at MORHAN and there were no refusals or withdrawals.
The interview is one of the tool that enables the access to mental processes, mainly senses and meanings. This must be consistent and sufficiently wide to avoid inadequate inferences(10). It was added the possibility that the interview works as a tool for the production and processing of the meanings in action.

The interview was based on a script focused on the meaning attributed to leprosy by these people, their experiences of life from diagnosis, treatment and care received at the healthcare services, discrimination and experience reports regarding the disease.

The register was carried out by digital recording with its transcription for data analysis, based on Vigotski's approach. This analysis technique was developed in workshops with the other authors and included three phases: initial reading of all material, identification of preindicators from the participants' speeches, agglutination of pre-indicators by similarity, complementarity or contraposition, and finally, organization process of the meaning $\operatorname{cores}^{(10)}$.

The Research Ethics Committee approved the project, Protocol number 01169812.0.0000.5393. In order to ensure the confidentiality of reports, respondents were identified in the presentation as E1, $E 2, E 3 \ldots E 8$, added by the letter $\mathrm{S}$ to respondents of the sulfonic period and by the letter $P$ for the period of multidrug therapy.

\section{Results}

From the data analysis, three meaning cores were constituted: spots on the body: something is out of order, leprosy or hanseniasis? and leprosy from the inclusion at MORHAN.

\section{Spots on the body: something is out of order}

In this first meaning core, it was highlighted the participants' speeches regarding the first signs of disease, mainly about the spots, emphasizing that something was not normal.

Sulfonic period

When those spots started to arise on my skin I asked her (wife) to separate from me in bed, all separated (ES4).

\footnotetext{
* The Vigotski name is found in the literature, spelled in various ways. In this work, we opted for the use of Vigotski spelling, however, it was preserved the original spelling in the references.
} 
I knew it was leprosy (...). I knew it caused those spots and I could not poke it (ES7).

Multidrug therapy period

I saw on television that any patch can be leprosy, and then I went to the doctor (physician). Suddenly a spot appears on your skin so you get very worried (EP1).

I had headache and aching spots. She (wife) told me to go to the doctor and I answered: Ah, make me a tea (...). I didn't want to go to the doctor because I was afraid of losing my job... (EP3).

\section{Leprosy or hanseniasis?}

The second meaning core is about the first contact of the participants with the health professional. They addressed the lack of knowledge about the disease and the feelings from the diagnosis.

Sulfonic period

He (physician) said I had leprosy (...). I didn't get nervous, if I have to go through it: it is for me and not for someone else (ES6).

I knew of it (leprosy) at the end of treatment. At first, he (physician) did not tell me anything (...) he told me after about three months (...). Well, maybe he had told and I did not understand (ES7).

I was playing soccer (...) and a doctor passed by and saw that I had a spot on my body that would not sweat (...) he applied the warm and hot test (...) after they put me into a police car and drove me to the leprosy hospital (...). Back then it was a dictatorship time, it was not called hospital, it was called leprosarium (ES8).

\section{Multidrug therapy period}

... the doctor (physician) said that if I followed the scheme of that remedy I'd get well. I could not drink or smoke (...). My whole family went to the hospital (...). I've got rid of that (EP3).

She (medical eye doctor) got mad, she said: what a nonsense, believe it, this is Hansen's disease. This is leprosy (...). What a nonsense, you have been untreated, so you are spreading it to population (...) she did not say it was leprosy (...) she just made a fuss (...). I got worried, I got scared, I told it was not my fault (EP5).

I knew of it (leprosy) because of the movie (Valley of the Lepers) (...) in the gospel, often there are comments on this disease. For me leprosy meant death (...) because that is what I watched in the film. (...) (EP2).

Still, in this second meaning core, another heavily discussed aspect is related to prejudice and stigma suffered by the respondents, which left scars in both treatment periods.

Sulfonic period

... When he (brother) saw me, he hid himself. He was afraid of the disease. And the brother of my sister in law had the same disease. I met him at the hospital (leprosarium) (ES6).

Once I was taken out from the bus, on the road, I had already been discharged from the hospital (...). There was a guy who knew that I had been hospitalized (...) he told I was sick. The bus driver stopped the bus and said to me: please, get off the bus? I answered: why? I have paid. He said: because you're a leper. I got off the bus and everyone was looking at me. Like an animal (...) I was left on the road ... (ES8).

Period of multidrug therapy

I commented (with a school friend) that I did the test and I had leprosy. At that time I was shocked (...) I did not tell to anyone (...). She was in front of me and took two steps back. It was like hitting me on the face... (EP2).

People knew that I had leprosy and they didn't close because they were afraid to be infected. I went to work and people said it was leprosy. I told it was not leprosy, it was hanseniasis. I lost friends, but after I am cured, the friendship started again. I felt scorned (...) there is mean people. We get hurt (EP3).

On the bus, people asked what it was (...) I answered that the doctor told it could be stress, (cancer) skin cancer, leprosy. When I used to say hanseniasis (...) the person responded: I hope it is not (...) I felt bad. Then, I started to say it was allergy (EP5).

\section{Hanseniasis from the inclusion at MORHAN}

It is highlighted, in the third meaning core, the importance that the survey participants attribute to MORHAN during treatment. It was also observed that, despite of being healed and participating intensely at MORHAN, some research participants still have ideas that are not consistent with the current information on leprosy.

\section{Sulfonic period}

It helped a lot (...) information. I learned more on leprosy. I met many people (ES4). 
About the current treatment, I know it is short. However, I do not know the medications or anything else (ES3).

I always attended (at MORHAN) the lectures and I always talked (...) if I saw the spots I recommended to visit a doctor (ES7).

I jointed the MORHAN to end up this prejudice (ES8).

Today (...) they say that you can get leprosy from the air. I do not believe it, because if the bacillus is exposed to the air, it dies (ES8).

Multidrug therapy period

I learned a lot, because what I had read had not convinced me. I talked a lot (at MORHAN). By exchanging ideas, more people came ... (EP2).

I do not know how to get contaminated (hanseniasis). I think I got it at the bus because I did not use to leave the house (...) I'm horrified, because a person (...) gets off (get off the bus seat) and another longer sits down. Sometimes the seat is so warm ... (EP2)

I learned more on what leprosy was (at Morhan). There were people who had the same disease (...). I do not know how to get leprosy (EP3).

\section{Discussion}

In the first meaning core "spots on the body: something is out of order" it is presented the meanings produced by the respondents, from the appearance of the first changes on the skin, the spots.

From the Vigotskian referential(8), it can be inferred that the spots on the body can be understood as signs, constituting a sort code for deciphering the world, the events and situations. It means that, the spots refer the individuals to the meaning of leprosy or something out the normal range, producing feelings of apprehension, fear and denial. Such meaning was identified from the life experiences and social relations of these individuals.

The exposure of images by the media, of people affected by leprosy, with hypochromic, brownish or reddish spots, also produce meanings, shared amongst the individuals and subsequently, internalized in a unique and complex manner. Advertising and general media produce meanings and cultural values(11).

The senses of leprosy to the respondents, in the sulfonic and multidrug therapy periods, sign the diversity of psychological aspects about normal and pathological, mediated by social, historical, economic and cultural contexts $^{(9)}$.
It is noteworthy that, in the sulfonic period, Brazil was experiencing industrialization, military dictatorship, rural exodus, urbanization and in the health area, the implementation of hospital-centered care model and health care assured only to formal contract workers. In the multidrug therapy period, the country experiencing the democratization and the fight for health as a citizenship right ${ }^{(4)}$.

The meanings presented by the respondents EP1, ES4 and ES7 are developed on the biologicist conception and by EP3 respondent, on the capitalist conception (man objectification), since to take care of yourself is not possible due to the possibility of losing the job. These meanings are similar in both periods and indicate the slow process of resignifying ${ }^{(9)}$, permeated by the senses and the experiences of the respondents.

According to some authors ${ }^{(12)}$, the carrier of hanseniasis is affected not only by the bacillus but also by an avalanche of psychological variables such as fear, anxiety, loneliness and depression, that impact on quality of life, self-care, evolution of the disease and physical disabilities.

In the second meaning core "leprosy or hanseniasis?", the respondents reported the stage of diagnosis and treatment of illness in the asylum-colonies (sulfonic period) and in the health services (multidrug therapy period).

In the sulfonic period, it is highlighted the meaning of the illness as a disease (leprosy), which causes changes in the skin sensitivity, "treated" at the leprosarium, from the medical knowledge and control of an authoritarian State ${ }^{(4)}$. The disease is surrounded by feelings of fear, stigmatization, social isolation and loss of civil rights (for example, a right to come and go).

This meaning was built and rebuilt historically by the social imaginary of leprosy as something evil(5), as well as by healthcare practices in Brazil focused on its control. The meaning reveals the fatalism (magicreligious view) as expressed by ES6, the subordination of the patient to medical knowledge-power as reported by ES7 and the control mechanisms as a result of an authoritarian State as narrated by ES8.

Some authors ${ }^{(3,13)}$ showed that the isolationist practice, especially in São Paulo, aimed to confine the leprosy patients as the only option for disease control. The prophylactic model adopted in São Paulo, based on isolationism, was consolidated between 1920 and 1930 with the construction of large asylum-colonies. A study ${ }^{(14)}$, carried out in the State of Santa Catarina, evidenced the stigma and prejudice experienced from the hospitalization. 
The isolation period in the asylum-colonies experienced by the participants of a research, produced psychological effects ${ }^{(14)}$. ES6 showed feelings of resignation, ES7 conformity, ES6 and ES8 sorrow, ES6 indignation and ES8 revolt. The individuals also revealed other effects related to the disease and the isolationist practice of the sulfonic period, such as stigmatization and social segregation, expressed by ES6 and ES8.

The prejudice, stigma and exclusion experienced by respondents of both forms of treatment are in accordance with this research findings ${ }^{(15)}$, pointing to the presence of discrimination into the family, at treatment places and, in this case, even in public transportation.

In the multidrug therapy period, it was evidenced the meaning of the illness as a disease (leprosy or Hansen's disease) that can be transmitted to family and population, if left untreated. The medical knowledgepower and the biopower(15) control the therapy as noted in the reports of EP3 and EP5. The disease and treatment are mediated by feelings of relief as expressed by EP3, guilt by EP5, despair and indignation by EP2 and sorrow by EP3 and EP5.

In both periods, the aspects related to biologicism, power-subordination between patient and physician, dehumanization of the healthcare and social marginalization are still present. However, these meanings point out, in the sulfonic period, a more fatalistic view of the disease that results in isolation. In the multidrug therapy period, additional information about the disease is emphasized, even though not accurate.

According to the Vigotskian referential, the objective meaning is constituted from the language use context, and is linked to emotional and personal aspects $^{(8)}$. Some respondents were told by the doctor that they had leprosy. Another respondent (EP2) told he knew of the disease from a movie and from evangelical legends citing the leper as something sinful and target of exclusion. Thus, the meanings were produced in conjunction with the senses attributed in unique experiences of each individual.

The findings suggest that leprosy is still loaded with stigmas $^{(16)}$ and negative meanings associated with the imaginary of leprosy. In addition, the construction of knowledge by the society about medical advances for the treatment and healing is still slow. It is noteworthy that the meanings are the basis of scientific knowledge and concepts.

The idea that there is a transformation of the meanings of these individuals, points out to an advance in the issues about the lack of knowledge of the disease in studies of leprosy in Brazil(17-20). It takes a while for the appropriation of the new meanings and their redefinition from the information disseminated.

In relation to health practices focused on hanseniasis treatment, some authors ${ }^{(20)}$ concluded that the professionals are still unprepared for the diagnosis, producing insecurity and anxiety in individuals affected by the disease. It was also demonstrated that the diagnosis, information and orientation might cause emotional impact on the individual, producing reactions such as denial and revolt, or even acceptance through a process that varies in time and intensity for each individual. Such aspect was evidenced in the speech of EP5 when referring to the inadequate way in which he was told about the diagnosis.

In the third meaning core "leprosy from the inclusion at MORHAN", respondents reported the importance of the movement to confront leprosy.

It was evidenced among the research participants (EP2, EP3, ES4, ES7 and ES8) that the mediation by MORHAN promoted changes in the perceptions of the disease from the acceptance, socialization of experiences and knowledge among members and activists. These meanings reveal aspects related to empowerment, social participation, autonomy, commitment and humanization, aiming at rehabilitation and social reintegration.

The MORHAN itself(5) emerges as a collective action in the transition from sulfonic to multidrug therapy period, representing the confrontation to the practices of isolation and stigmatization, and for this reason, it included people treated in both periods.

Despite the existence of considerable literature on the history of leprosy, there is prevalence the studies focused on oppression and domination that the former patients were submitted. Although there are few studies presenting the forms of resistance and political fights generated by these individuals ${ }^{(5)}$. This is possible from the transformation of meanings that can lead to action.

Another study(5) demonstrates how individuals are not only influenced by stigmatizing images or by discipline networks of the asylum-colonies, but also act politically to change the meanings of leprosy.

It was also observed that despite the healing and intense participation at MORHAN, some research individuals (EP2, EP3 and ES8) have not internalized knowledge on the ways of disease transmission.

The fact of maintaining the "not knowing" about basic aspects of leprosy, even participating in MORHAN activities and receiving advises from others people with 
respect to the form of respiratory infection of leprosy, confirms that the practices of mere transmission of information are not enough to change some meanings.

These are constructed throughout the history of human groups, based on the relationship of men with the physical and social world in which they live(8). Consequently, the meanings transmitted by cultural groups are in constant development. The listening, interaction, dialogue and meetings are possibilities for internalization and consequent re-signification, keeping the singularities. In this sense, it is important to mention the expression often used by healthcare workers: each case is different.

\section{Conclusion}

The meanings of leprosy for people treated in the sulfonic and multidrug periods point out to the complex construction thereof, indicating differences and similarities in both periods.

It was highlighted the three meaning cores. In the first, "spots on the body: something is out of order", the predominant meanings are the spots indicating something out of the normal range and producing feelings of apprehension, fear and denial. Although they have been treated in different periods, the meanings are similar, because they reflect the slow change in society regarding the health/disease process

In the second core, "leprosy or hanseniasis?", the meanings are related to biologicism, subordination to the medical power, stigmatization and dehumanization of the assistance provided to individuals in both periods. However, it is highlighted a magical and fatalistic view in the individuals of the sulfonic period in contraposition to the presence of more information, albeit inaccurate, about the disease in the multidrug therapy period.

The prejudice was observed to respondents treated by multidrug therapy and sulfones, remaining even after the change of the name of disease from leprosy to hanseniasis.

The third core, "leprosy from the inclusion at MORHAN" reveals experiences of concrete actions of the individuals to deal with the meanings constructed throughout their lives in each period. These are related to empowerment, social participation, autonomy, acceptance and humanization, aiming at the rehabilitation and social reintegration. The MORHAN emerges as a collective action in the transition between the sulfonic and multidrug periods, representing resistance to the isolation and stigmatization practices.
The MORHAN became a socially important movement, able to offer support to people with leprosy and their families, so they can re-signify the multiple issues surrounding leprosy and not just sharing information.

Even if some individuals have not yet re-signified leprosy regarding its way of transmission, treatment and cure, it is still possible to carry out this change, by means of dialogues and reflections, considering the unfinished production of meanings.

The health professionals, mainly the nursing ones, considering the aspects presented here, can assist people with leprosy and their families, answering questions, supporting, listening, talking and trying to understand peculiarities of each person and the context in which they live. This perspective can encourage the production of new meanings on the disease.

In implementing this study, it was difficult to confront these findings with other studies dealing with the theme leprosy, by considering the theoretical framework adopted. A limitation of this study was not adopting the interviewer records regarding the production process of her own meanings about leprosy, built and transformed from the meeting with the respondents, which could enrich the analysis.

\section{Acknowledgments}

To the Movement of Reintegration of Persons Afflicted by Hansen's disease (MORHAN), for its support and for allowing the completion of data collection.

\section{References}

1. Ministério da Saúde (BR). Vigilância em saúde: Dengue, Esquistossomose, Hanseníase, Malária, Tracoma e Tuberculose. Brasília: Ministério da Saúde; 2008.

2. Ministério da Saúde (BR). Manual de Incapacidades. Brasília: Ministério da Saúde; 2008.

3. Monteiro YN. Prophylaxis and exclusion: compulsory isolation of Hansen's disease patients in São Paulo. Hist Cienc Saude-Manguinhos. 2003;10(Suppl 1):95-121.

4. Araújo AMA, Sousa ACM, Minuzzo DA, Souza ES, Silva LDA, Nascimento VT. Dossiê: a história dos filhos órfãos de pais vivos no Brasil [Internet]. jul. 2012. Rio de Janeiro; 2010 [acesso 1 jul 2014] Disponível em: www. morhan.org.br/views/upload/Dossie_Filhos.pdf

5. Mendonça RF. Táticas cotidianas e ação coletiva: a resistência das pessoas atingidas pela hanseníase. Varia Hist. $2012 ; 28(47): 339-58$. 
6. Fava SMCL, Nunes ZB, Gonçalves MFC. Abordagem Histórico-Cultural como Referencial Teórico para Pesquisa em Enfermagem. Reas. 2013;2(2):107-15.

7. Vigotski LS. A formação social da mente. São Paulo: Martins Fontes; 2014.

8. Vigotski LS. A construção do pensamento e da linguagem. São Paulo: WMF Martins Fontes; 2009.

9. Góes MCR, Cruz MN. Sentido, significado e conceito: notas sobre as contribuições de Lev Vigotski. ProPosições. 2006;17(2):31-45.

10. Aguiar WM, Ozella S. Núcleos de Significação como Instrumento para Apreensão da Constituição dos Sentidos. Psicol, Ciênc Prof. 2006;26(2):222-45.

11. Prange $B$, Bragagnolo RI. As singularidades das crianças pequenas expressas nas suas brincadeiras. Educ. Real. 2012;37(1):251-71.

12. Palmeira IP, Queiroz ABA, Ferreira MA. Marcas em si: vivenciando a dor do (auto) preconceito. Rev Bras Enferm. 2013;66(6):893-900.

13. Mellagi AG, Monteiro YN. O imaginário religioso de pacientes de hanseníase: um estudo comparativo entre ex-internos dos asilos de São Paulo e atuais portadores de hanseníase. Hist Cienc Saude-Manguinhos. 2009;16(2):489-504.

14. Borenstein MS, Padilha MI, Costa E, Gregório VRP, Koerich AME, Ribas DL. Hanseníase: estigma e preconceito vivenciados por pacientes institucionalizados em Santa Catarina (1940-1960). Rev Bras Enferm. 2008;61(n.spe):708-712.

15. Saraiva K. Educando para viver sem riscos. Educação (Porto Alegre). 2013:36(2):168-79.

16. Goffman E. Estigma: notas sobre a manipulação da identidade deteriorada. Rio de Janeiro: Zahar; 1982.

17. Nations MK, Lira GV, Catrib AMF. Stigma, deforming metaphors and patients' moral experience of multibacillary leprosy in Sobral, Ceará State, Brazil. Cad Saúde Pública. 2009;25(6):1215-24.

18. Bittencourt LP, Carmo AC, Leão AMM, Clos AC. Estigma: percepções sociais reveladas por pessoas acometidas por hanseníase. Rev Enferm UERJ. 2010;18(2):185-90.

19. Cid RDS, Lima GG, Souza AR, Moura ADA. Percepção de usuários sobre o preconceito da hanseníase. Rev Rene. 2012;13(5):1004-14.

20. Silva RCP, Lopes A, Guisard CLMP, Peixoto ES, Metello HN, Ito LS, et al. História de vida e trabalho de pessoas atingidas pela hanseníase em Serviços de Saúde do Estado de São Paulo. Hansen Int. 2008;33(1):9-18. 